\title{
FIRST RECORD OF THE GENUS NEOMICRODISPUS (ACARI: MICRODISPIDAE) FROM RUSSIA WITH THE DESCRIPTION OF A NEW SPECIES AND A KEY TO WORLD GENERA OF THE FAMILY MICRODISPIDAE
}

\author{
Alexander A. Khaustov \\ Tyumen State University, Tyumen, Russia \\ e-mail: alex1973khaustov@gmail.com \\ ABSTRACT: Neomicrodispus sibiriensis sp.n. (Acari: Microdispidae), collected from a decaying tree stump in Western Siberia, \\ Russia, is described. After studying the type material for Neomicrodispus iranicus Hajiqanbar et Hosseininaveh, 2014, the diag- \\ nosis of the genus Neomicrodispus Hajiqanbar et Hosseininaveh, 2014 was modified. In addition, a key to the world genera of
} the family Microdispidae is provided.

KEY WORDS: Mites, Heterostigmata, systematics, Western Siberia, SEM microscopy.

DOI: 10.21684/0132-8077-2018-26-2-175-182

\section{INTRODUCTION}

The family Microdispidae Cross, 1965, which currently includes 27 genera and more than 120 species, is the least diverse and the least studied family of pygmephoroid mites (Khaustov 2017; Khaustov et al. 2018; Khaustov and Ermilov 2018; Khaustov and Frolov 2018; Azhari et al. 2018). Most microdispid mites are fungivorous, but some species are parasitoids of insects (Kaliszewski et al. 1995). Many microdispid species are incompletely described, and their taxonomic position is unclear (Khaustov 2017). A lack of a key to the genera of the family Microdispidae causes problems with the correct placement of many species in their proper genera. The previous key to the genera of the family Microdispidae was published by Mahunka (1970). Since that time, many microdispid genera have been described or redefined (Mahunka 1972, 1975, 1977a, b, 1978; Kaliszewski and Rack 1986; Mahunka and Mahunka-Papp 1994; Khaustov 2006, 2009, 2014; 2017; Hajiqanbar and Hosseininaveh 2014; Khaustov and Tolstikov 2015; Khaustov and Minor 2016; Khaustov and Zelalem 2017; Azhari et al. 2018; Khaustov et al. 2018; Khaustov and Ermilov 2018). In this paper, I provide a key to the world genera of Microdispidae.

During my study of heterostigmatic mites of Western Siberia, I recorded a new species Neomicrodispus sibiriensis sp.n. that belongs to a rare genus. After studying the type material of Neomicrodispus iranicus Hajiqanbar et Hosseininaveh, 2014, I concluded that the original description of Neomicrodispus iranicus lacks some important taxonomic characters. Consequently, this paper contains a modified diagnosis of the genus Neomicrodispus.

\section{MATERIAL AND METHODS}

The mites were collected from samples taken from a decaying tree stump, using Berlese funnels and mounted in Hoyer's medium. The holotype and one paratype of Neomicrodispus iranicus were loaned from the collection of Tarbiat Modares University (Tehran, Iran). Mite morphology was studied using a Carl Zeiss AxioImager A2 compound microscope, equipped with a phase contrast and DIC objectives. For SEM microscopy, alcohol-preserved mites were freeze-dried in JFD 320 (JEOL, Japan), coated in gold, and then scanned with the aid of a JEOL JSM-6510LV SEM microscope.

The terminology of the idiosoma and legs follows that of Lindquist (1986); the nomenclature of subcapitular setae and the designation of cheliceral setae follow Grandjean (1944, 1947), respectively. The taxonomic system of Pygmephoroidea follows that of Khaustov $(2004,2008)$. All measurements for the holotype and five paratypes (in parentheses) are provided in micrometers $(\mu \mathrm{m})$. For leg chaetotaxy, the number of solenidia is provided in parentheses.

\section{RESULTS}

Family Microdispidae Cross, 1965

Genus Neomicrodispus Hajiqanbar et Hosseininaveh, 2014

Type species: Neomicrodispus iranicus Hajiqanbar et Hosseininaveh, 2014, by original designation.

Diagnosis. As in Hajiqanbar and Hosseininaveh (2014), with the following modifications. 
Gnathosoma. Postpalpal setae ( $p p$ ) present. Idiosomal venter. Setae $4 a$ present or absent. Legs. Setation of tibiotarsus I - 15(3) $\left(d, l\right.$,,$l^{\prime}$, $v^{\prime}, v^{\prime \prime}, k, t c^{\prime}, t c^{\prime \prime}, f t^{\prime}, f t^{\prime \prime}, p^{\prime \prime}, p l^{\prime}, p l l^{\prime}, p v^{\prime}, p v^{\prime \prime}, \omega_{1}$, $\left.\varphi_{1}, \varphi_{2}\right)$. Tibia IV without solenidion.

\section{Neomicrodispus sibiriensis sp.n.}

(Figs. 1-4)

Description. Female (Figs. 1-4). Length of idiosoma 175 (165-175), width 110 (100-110).

Gnathosoma. Length of gnathosoma 22 (22$23)$, width 13 (12-14). Dorsal median apodeme absent. Cheliceral setae cha 13 (12-13) weakly barbed and pointed (Figs. 4B-D). Postpalpal setae $(p p)$ needle-like, located laterally to bases of $c h a$ (Fig. 4D). Setae $d F e$ and $d G e$, smooth, pointed, subequal. Subcapitular setae $m 8$ (8-9) smooth and pointed. Accessory setigenous structure (ass) short, cylindrical. Subcapitulum with oval pits in posterior part. Pharyngeal pump I small, bow-shaped, smooth, distinctly separated from large subrectangular and transversely striated pump II; pharyngeal pump III small, smooth, located just behind pump II.

Idiosomal dorsum (Fig. 1A). Prodorsum only slightly covered by anterior part of tergite C. All dorsal shields with numerous very small round dimples. All dorsal hysterosomal setae sparsely barbed and pointed. Trichobothria with long stem, clavate, weakly barbed, with two short apical projections. Cupules $i a$ and $i h$ small, round. Posterior parts of tergites $\mathrm{C}, \mathrm{D}, \mathrm{EF}$ and lateral plates with row of $\mathrm{u}$-shaped elevations. Tergite $\mathrm{C}$ with two pairs of oval porous areas medially to setae $c_{1}$ and one pair laterally to $c_{1}$; tergite $\mathrm{EF}$ with one pair of round porous areas just anterior to bases of setae $e$; tergite $\mathrm{H}$ with one pair of porous areas medially to setae $h_{1}$. Posterior margin of tergite $\mathrm{H}$ with short and wide $\mathrm{u}$-shaped projection. Lengths of dorsal setae: $s c_{2} 26$ (24-29), c 38 (34-39), c 37 (34-38), $d 40$ (40-43), e 38 (37-39), f 42 (41-46), $h_{1} 35$ $(35-37), h_{2} 23$ (23-25). Distances between setae: $s c_{2}-s c_{2} 36$ (35-37), $c_{1}-c_{1} 45$ (42-46), $c_{1}-c_{2} 22$ (21-23), $d-d 21$ (20-22), e-f 21 (19-22), $f-f 23$ (21-23), $h_{1}-h_{1} 35$ (33-35), $h_{1}-h_{2} 11$ (10-11).

Idiosomal venter (Figs. 1B, 4A, B, E). Apodemes 1 (ap1), apodemes 2 (ap2) and sejugal apodeme (apsej) well developed and joined with prosternal apodeme (appr); apodemes 3 (ap3) weak, linear, joined with poststernal apodeme (appo); apodemes 4 (ap4) well developed, reaching beyond bases of setae $3 b$. Apodemes 5 absent. Ventral plates with numerous very small round dimples. All ventral setae pointed. Setae $3 b, 4 a$ and $4 b$ smooth; setae $3 a$, $3 c, 4 c$ and $p s_{1-3}$ with few weak barbs; other ventral setae distinctly barbed. Posterior part of poststernal plate and aggenital plate with u-shaped elevations. Posterior margin of posterior sternal plate weakly convex in middle part. Posterior margin of aggenital plate almost straight. Anterior (ags) and posterior (pgs) genital sclerites small, bell-like. Lengths of ventral setae: $1 a 21$ (21-23), $1 b 18$ (18-20), $2 a$ 28 (24-29), $2 b 30$ (30-32), $3 a 24$ (24-25), $3 b 30$ (25-30), 3c 22 (22-23), 4a 27 (27-30), $4 b 44$ (44-46), 4c 35 (35-37), ps 13 (11-13), ps 12 (11-12), ps 13 (12-13).

Legs (Figs. 2, 3, 4F). Leg I (Figs. 2A, 4F). Lengths of solenidia $\omega_{1} 9(9-10), \varphi_{1} 6(6), \varphi_{2} 6(6)$; $\varphi_{1}$ clavate, $\omega_{1}$ finger-shaped, $\varphi_{2}$ uniformly thin. Setae $l$ ' of femur and $k$ of tibiotarsus blunt-ended; other leg setae (except eupathidia) pointed. Seta $v^{\prime}$ of trochanter smooth; other leg setae (except eupathidia) barbed. Leg II (Fig. 2B). Tarsus with claws distinctly thickened in basal part and with flipper-like empodium. Solenidion $\omega 7$ (7-8) finger-shaped, solenidion $\varphi 3$ (3) weakly clavate. All leg setae pointed and barbed. Leg III (Fig. 3A). Claws and empodium as on tarsus II. Solenidion $\varphi 2$ (2) weakly clavate. All leg setae pointed and barbed. Leg IV (Fig. 3B). Tarsus with simple hooked claws and small empodium. All leg setae pointed and barbed.

Male and larva unknown.

Differential diagnosis. The new species can be distinguished from $N$. iranicus by the presence of setae $4 a$ (absent in $N$. iranicus) and distinctly longer dorsal hysterosomal setae.

Type material. Female holotype, slide ZISP T-Mcd-002, Russia, Tyumen Region, vicinities of lake Kuchak, $57^{\circ} 21^{\prime} \mathrm{N}, 66^{\circ} 03^{\prime} \mathrm{E}$, in a decaying stump, 1 August 2018, coll. A.A. Khaustov; paratypes: 8 females, same data; 2 females, same locality, 26 September 2018.

Type deposition. The holotype and two paratypes are deposited in the collection of the Zoological Institute of Russian Academy of Sciences (St. Petersburg, Russia), other paratypes in the collection of the Tyumen State University Museum of Zoology, Tyumen, Russia.

Etymology. The name of the new species refers to its distribution in Siberia.

\section{Neomicrodispus iranicus Hajiqanbar et Hosseininaveh, 2014}

Neomicrodispus iranicus Hajiqanbar et Hosseininaveh, 2014, p. 2, Figs. 1-5. 


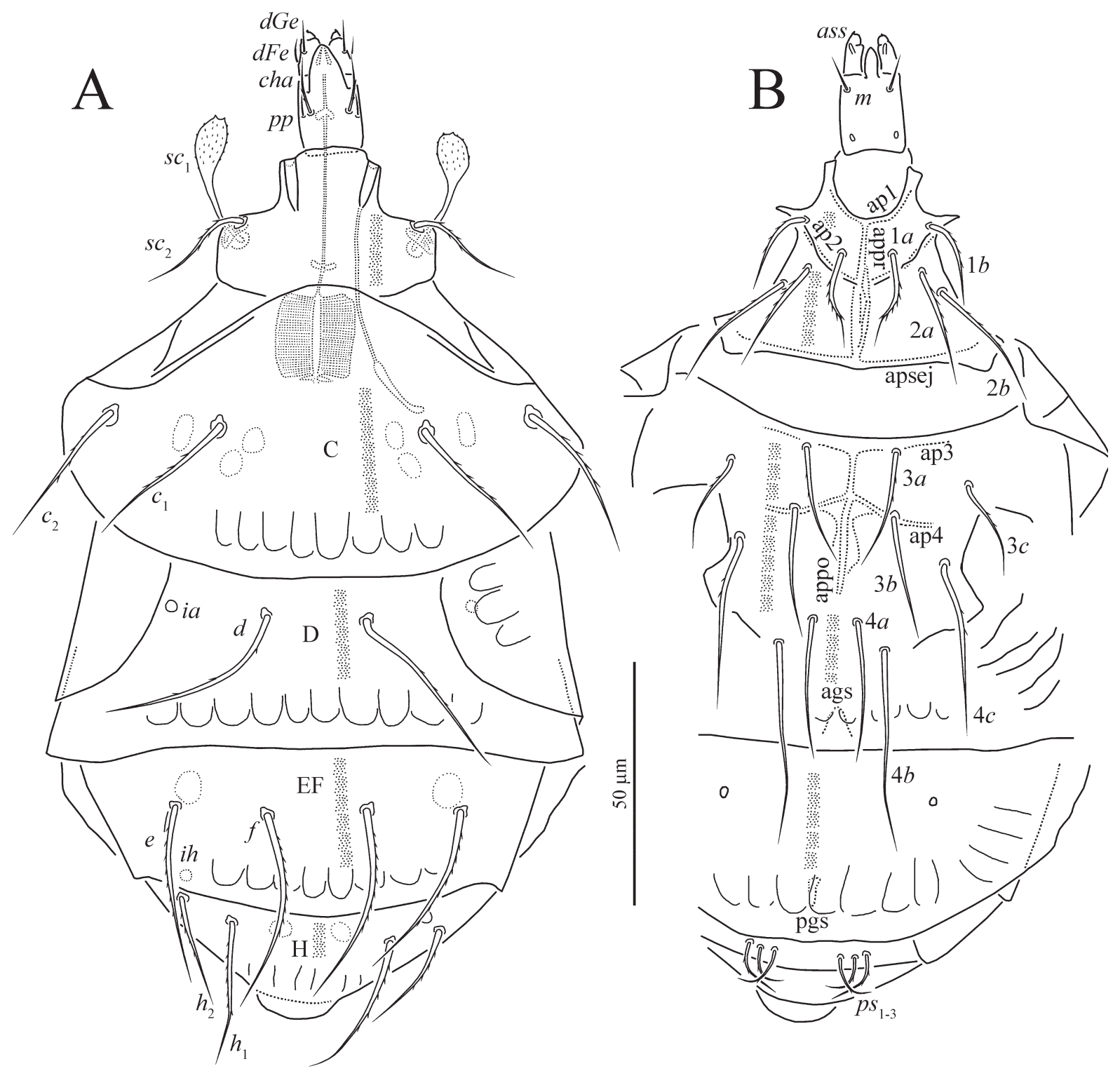

Fig. 1. Neomicrodispus sibiriensis sp.n., female: A—dorsum of the body, B—venter of the body. Legs omitted.

Material examined. Female holotype (VR20100715) and one paratype found in a vial containing the beetle Oryctes nasicornis (Coleoptera: Scarabaeidae) and ethyl alcohol $75 \%$. The host beetle was collected in Naharkhoran forest, Golestan Region, northern Iran, $36.46^{\circ} \mathrm{N}, 54.27^{\circ}$ E, altitude 450 m., coll. V. Rahiminejad, 15 July 2010.

Remarks. Examination of the type material of this species revealed that it has the same setation of leg I as $N$. sibiriensis sp.n. In the original description, only four eupathidia were depicted on tibiotarsus I. In fact, five eupathidia are present. Postpalpal setae are present (vs. absent in the original description). Trichobothria are barbed, with two short apical projections (vs. smooth and without projections in the original description). Setae $e$ and $h_{2}$ are weakly barbed (vs. smooth in the original description). Tibia IV is without solenidion, but with pore-like structure, visible on its typical insertion point (vs. with solenidion in the original description).

\section{Key to world genera of Microdispidae}

(based on females)

1. Tibiotarsus I with claw. .2

- Tibiotarsus I without claw................................6

2. Body round, gnathosoma very long, beak-like... Perperipes Cross, 1965

— Body oval, gnathosoma not beak-like............. 3

3. Tarsus IV with pretarsus, claws and empodium ... 4 - Tarsus IV without pretarsus, claws and empodium.. .Proreductodispus Khaustov et Tolstikov, 2015 


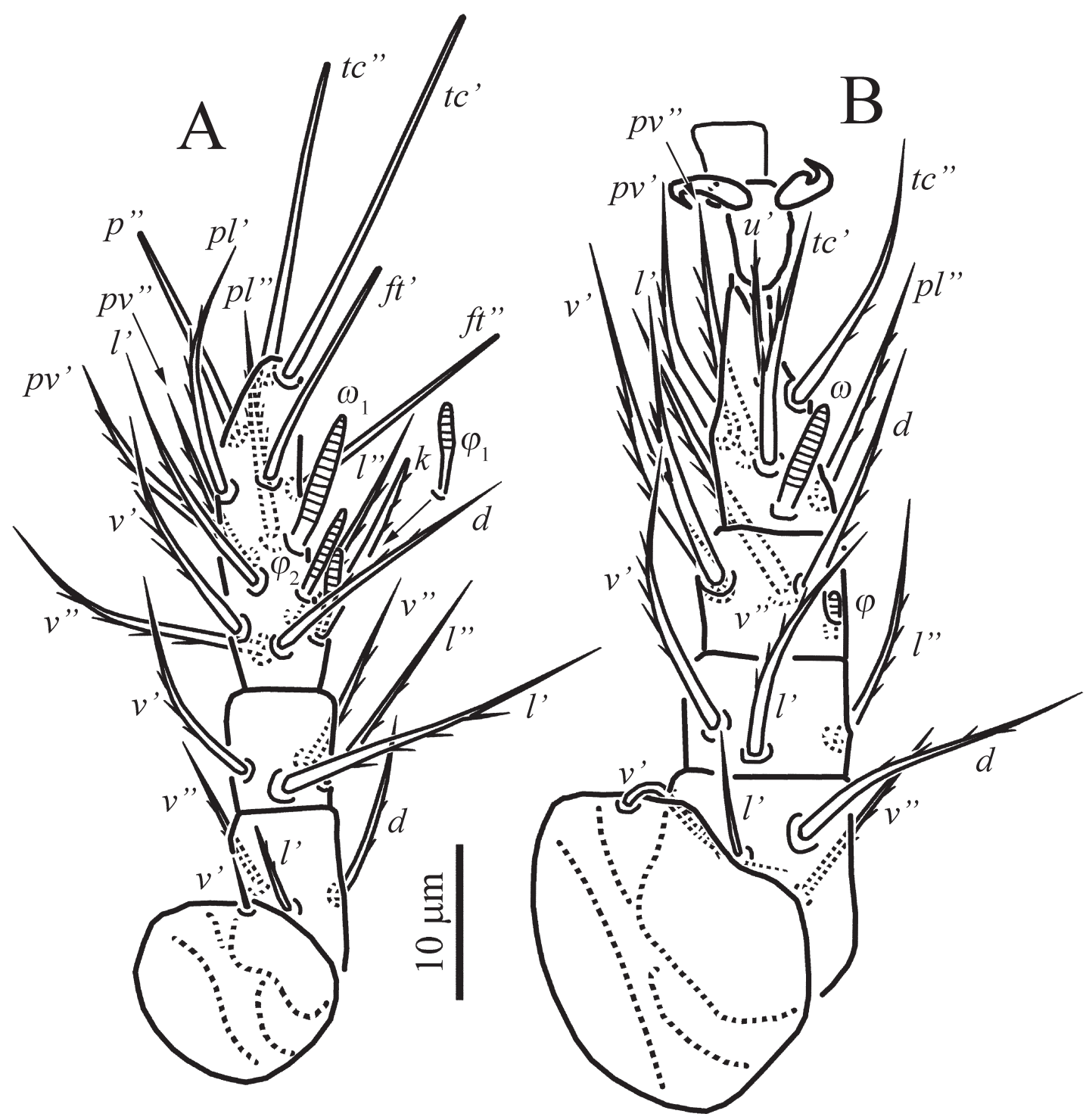

Fig. 2. Neomicrodispus sibiriensis sp.n., female: A—right leg I in dorsal view, B—right leg II in dorsal view.

4. Posterior margin of posterior sternal plate with three large lobes (tripartite).

- Posterior margin of posterior sternal plate without lobes Unguidispus Mahunka, 1970 5. Legs I distinctly shorter and thinner than legs II, seta $t c$ ' present on tarsus III, tibia IV with seta $v$ ".. Myrmecodispus Cross, 1965 — Legs I and II subequal in length and width, seta $t c$ ' absent on tarsus III, tibia IV without seta $v$ "... .Afrodispus Khaustov, 2017 6. Gnathosomal capsule elongate, palps distinct .. 7 - Gnathosomal very wide, about twice wider than length, palps indistinct.....Peponocara Cross, 1965 7. Tarsus IV without pretarsus, claws and empodium

— Tarsus IV with pretarsus, claws and empodium
8. Dorsal hysterosomal setae not modified Reductodispus Mahunka, 1977 - Dorsal hysterosomal setae $d$, $e$ and $f$ modified, wide and tube-like

Tubulodispus Mahunka, 1975 9. Gnathosoma usually not beak-like, if distinctly narrowed distally than setae $p l$ "' and $t c$ ' on tarsi II and III not modified

- Gnathosoma very long, beak-like, setae $p l$ " and tc' on tarsi II and III strongly widened, bluntended. Glyphidomastax Cross, 1965 10. Trichobothria present 11

- Trichobothria absent

..Ethiodispus Khaustov, 2017 11. Femur I with two setae, femur II with one seta, genua III and IV without setae, seta $p l$ " on tarsi II-IV absent 

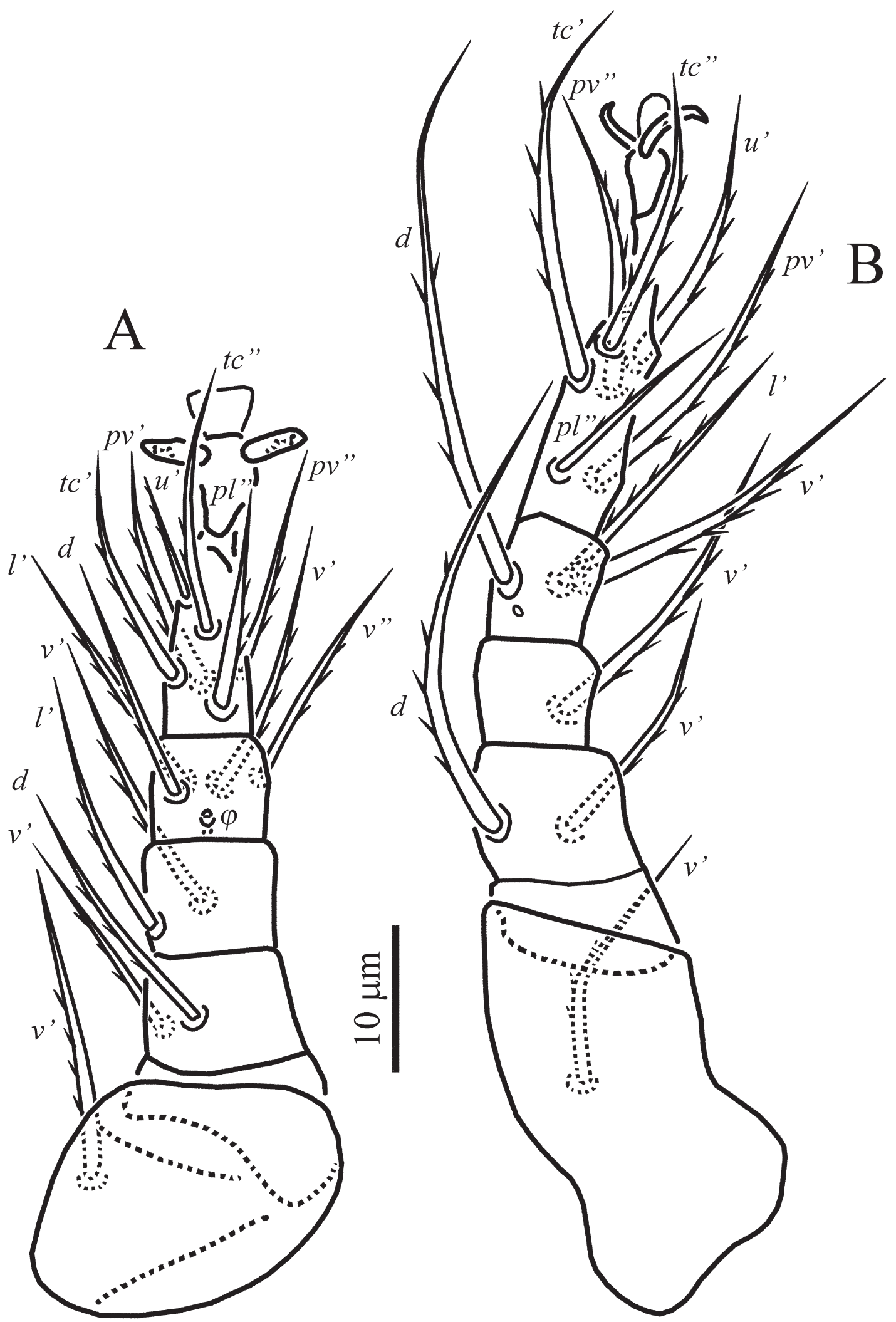

Fig. 3. Neomicrodispus sibiriensis sp.n., female: A—right leg III in dorsal view, B—right leg IV in dorsal view.

— Femur I usually with three setae, femur II with three setae, genua III and IV with setae, seta $p l$ ", on tarsi II-IV present
12. Tarsi II and III with setae $u^{\prime}$

Phyllodispus Mahunka, 1970 


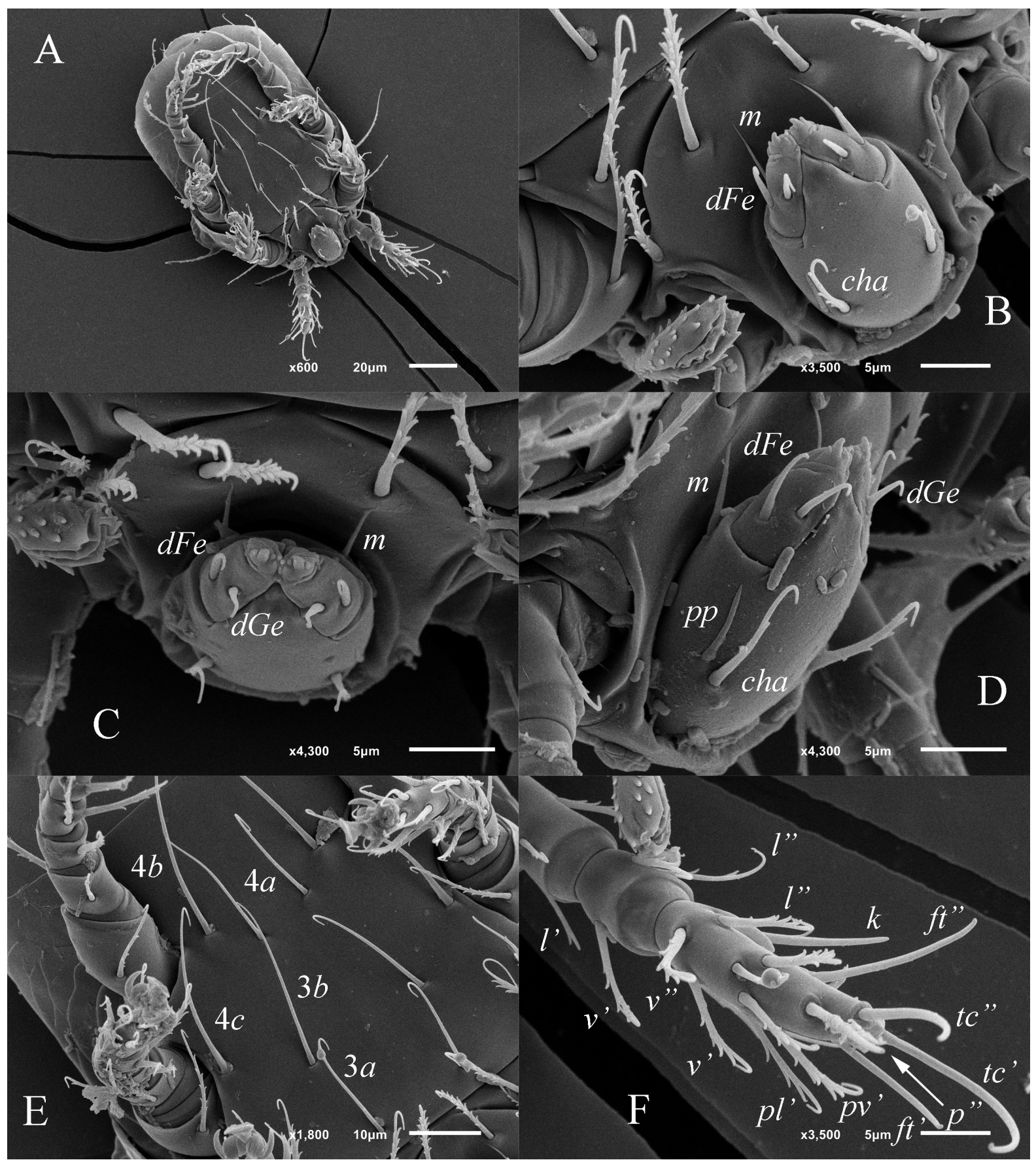

Fig. 4. SEM micrographs of Neomicrodispus sibiriensis sp.n., female: A — body in ventral view, B — prosoma in ventral view, C-gnathosoma in frontal view, D-gnathosoma in dorsolateral view, E-posterior sternal plate, F-leg I in ventral view.

— Tarsi II and III without setae $u^{\prime}$.....

.Paraphyllodispus Khaustov et Minor, 2016 13. Eupathidium $f t$ ' absent on tibiotarsus I ....... 14 - Eupathidium $f t$ ' present on tibiotarsus I....... 17 14. Eupathidium $f t$ " present on tibiotarsus I.....15 — Eupathidium $f t$ " absent on tibiotarsus I ........... Microdispus Paoli, 1911

15. Tibia IV with three setae .16

— Tibia IV with four setae Paramicrodispus Khaustov, 2009
16. Setae $h_{1}$ always modified (leaf-like, strongly expanded and flattened), most of dorsal setae usually strongly barbed, sometimes ventral setae $4 a$ and $4 b$ modified, flattened and expanded), eupathidium $f t$ " well developed

Cochlodispus Mahunka, 1972 - Setae $h_{1}$ only slightly thickened, most of dorsal setae usually weakly barbed, ventral setae $4 a$ and $4 b$ not modified, eupathidium $f t$ " very short.

..Pseudomicrodispus Khaustov, 2017 
17. Genu IV with four setae 18

- Genu IV with three setae

... Neomicrodispus Hajiqanbar et Hosseininaveh, 2014 18. Body oval or elongate, dorsal hysterosomal setae not modified.... .19

- Body almost round, at least setae $f$ and $h_{1}$ flattened, widened and lanceolate

.... Scutodispus Mahunka et Mahunka-Papp, 1994 19. Posterior margin of posterior sternal plate entire or at least with very weak median lobe. 20

- Posterior margin of posterior sternal plate distinctly tripartite, with large median lobe 23 20. Gnathosoma no more than two times longer than wide. 21 - Gnathosoma more than two times longer than wide. Rostrodispus Mahunka, 1969 21. Legs I and II subequal in length, palptibia without triangular dorsal projection. Not associated with ants ...22 - Legs I distinctly shorter and thinner than leg II, palptibia with triangular dorsal projection. Associated with ants ...... Caesarodispus Mahunka, 1977 22. Lateral margins of tergite $\mathrm{C}$ form distinct angle........... Rhombomicrodispus Khaustov, 2017 — Lateral margins of tergite $\mathrm{C}$ rounded

..Promicrodispus Khaustov, 2017

23. Pharyngeal pump III oval, much larger than pump I.

- Pharyngeal pump III vestigial, subequal with pump I..... ...25

24. Gnathosoma about 1.5-2 times longer than wide, seta $t c$ ' on tarsus IV not situated on protuberance Premicrodispus Cross, 1965 — Gnathosoma about three times longer than wide, seta $t c$ ' on tarsus IV situated on protuberance ...... Vietodispus Mahunka, 1975 25. Anterior margin of tergite $\mathrm{C}$ with large semioval lobe. . .26 - Anterior margin of tergite $\mathrm{C}$ without lobe........ .Punicodoxa Mahunka, 1978

26. Setae $(p v)$ on tibiotarsus I absent, gnathosoma about two times longer than wide, claws on tarsi II and III with thickened bases ...... Parapunicodoxa Khaustov, Hugo-Coetzee et Ermilov, 2018

- Setae $(p v)$ on tibiotarsus I present, gnathosoma as long as wide, claws on tarsi II and III simple...

.Dolichodispus Khaustov, 2006

\section{ACKNOWLEDGEMENTS}

The author thanks Dr. Hamidreza Hajiqanbar (Tarbiat Modares University, Tehran, Iran) for loaning the type specimens of Neomicrodispus iranicus; and A.N. Bobylev (Tyumen State University, Tyumen, Russia) for SEM micrographs.

\section{REFERENCES}

Azhari, S., Hajiqanbar, H. and Talebi, A.A. 2018. First record of the genus Punicodoxa (Acari: Microdispidae) from Asia, with description of a new species phoretic on termites (Insecta: Isoptera). Systematic and Applied Acarology, 23 (3): 468-476.

Grandjean, F. 1944. Observations sur les Acariens de la famille des Stigmaeidae. Archives des Sciences Physiques et Naturelles, 26: 103-131.

Grandjean, F. 1947. L'origine pileuse des mors et la chaetotaxie de la mandibule chez les Acariens actinochitineux. Comptes rendus des Séances de l'Academie des Sciences, 224: 1251-1254.

Hajiqanbar, H. and Hosseininaveh, F. 2014. A new genus and species of the family Microdispidae (Acari: Prostigmata) associated with Oryctes nasicornis (Coleoptera: Scarabaeidae) and redescription of the monotypic genus Vietodispus Mahunka, 1975. Zoological Studies, 53: 58. DOI: 10.1186/ s40555-014-0058-7

Kaliszewski, M., Athias-Binche, F. and Lindquist, E.E. 1995. Parasitism and parasitoidism in Tarsonemina (Acari: Heterostigmata) and evolutionary considerations. Advances in Parasitology, 35: 335-367.

Kaliszewski, M. and Rack, G. 1986. A systematic study of the mite Microdispus (Premicrodispus) lambi (Krczal, 1964) (Acari: Pygmephoroidea), a mushroom pest in Australia. Mitteilungen aus dem Hamburg Zoologischen Museum Institute, 83: 231-241.

Khaustov, A.A. 2004. [Mites of the family Neopygmephoridae Cross, 1965 stat. n. and their position in Heterostigmata]. In: Y.S. Balashov (Ed.). VIII Russian Acarological Conference, St.Petersburg. Zoological Institute of RAS, St. Petersburg, p. 137. [In Russian]

Khaustov, A.A. 2006. A review of the genera Premicrodispus Cross, 1965 and Dolichodispus gen. nov. (Acari: Microdispidae) of Crimea. Acarina, 14 (2): 155-174.

Khaustov, A.A. 2008. Mites of the family Scutacaridae of Eastern Palaearctic. Akademperiodyka, Kiev. $291 \mathrm{pp}$.

Khaustov, A.A. 2009. A new genus and three new species of the mite family Microdispidae (Acari: Heterostigmata) from Crimea. Acarina, 17: 65-73.

Khaustov, A.A. 2014. A review of myrmecophilous mites of the family Microdispidae (Acari: Heterostigmatina) of Western Siberia. ZooKeys, 454: 13-28. 
Khaustov, A.A. 2017. Contribution to systematics of the Palaearctic Microdispidae (Acari: Pygmephoroidea). International Journal of Acarology, 43: 475-493.

Khaustov, A.A and Ermilov, S.G. 2018. New species and new records of Microdispidae (Acari: Pygmephoroidea) from Zanzibar, Tanzania. Systematic and Applied Acarology, 23 (10): 1891-1906.

Khaustov, A.A. and Frolov, A.V. 2018. A new species, new genus and new records of heterostigmatic mites (Acari: Heterostigmata) phoretic on scarab beetles of the subfamily Orphninae (Coleoptera: Scarabaeidae). Zootaxa, 4514 (2): 181-201.

Khaustov, A.A., Hugo-Coetzee, E. and Ermilov S.G. 2018. New taxa of the family Microdispidae (Acari: Heterostigmata) associated with Trinervitermes trinervoides (Sjostedt) (Isoptera: Termitidae) from South Africa. International Journal of Acarology, DOI: 10.1080/01647954.2018.1515247

Khaustov, A.A. and Minor, M.A. 2016. New taxa and record of mite family Microdispidae (Acari: Heterostigmata) from alpine New Zealand. International Journal of Acarology, 42: 159-167.

Khaustov, A.A. and Tolstikov, A.V. 2015. A new genus and two new species of the family Microdispidae (Acari: Pygmephoroidea) from southern Chile. International Journal of Acarology, 41: 642-649.

Khaustov, A.A. and Zelalem, W. 2017. Two new genera of mite family Microdispidae (Acari: Heterostigmata) associated with Macrotermes subhyalinus (Isoptera: Termitidae) from Ethiopia. International Journal of Acarology, 43: 223-231.

Lindquist, E.E. 1986. The world genera of Tarsonemidae (Acari: Heterostigmata): a morphological, phylogenetic, and systematic revision, with a reclassification of family-group taxa in the Heterostigmata. Memoirs of Entomological Society of Canada, 118: 1-517.

Mahunka, S. 1970. Considerations on the systematics of the Tarsonemina and the description of new European taxa (Acari: Trombidiformes). Acta Zoologica Academiae Scientiarum Hungaricae, 16: 137-174.

Mahunka, S. 1972. The first survey of the Tarsonemid (Acari) fauna of New Guinea. I. Acta Zoologica Academiae Scientiarum Hungaricae, 18 (1-2): 41-92.

Mahunka, S. 1975. Äthiopische Tarsonemiden (Acari: Tarsonemida), I. Acta Zoologica Academiae Scientiarum Hungaricae, 21 (3-4): 305-322.

Mahunka, S. 1977a. Neue und interessante Milben aus dem Genfer Museum XIX. Einige Angaben zur Kenntnis der Milbenfauna der Ameisen-Nester (Acari: Acarida, Tarsonemida). Archives des Sciences. Geneve, 30 (1): 91-106.

Mahunka, S. 1977b. The examination of myrmecophilous tarsonemid mites based on the investigations of Dr. C.W. Rettenmeyer (Acari). I. Acta Zoologica Academiae Scientiarum Hungaricae, 23: 99-132.

Mahunka, S. 1978. Beiträge zur Kenntnis der Tarsonemiden-Fauna (Acari: Tarsonemida) Tunesiens. Parasitologia Hungarica, 11: 113-125.

Mahunka, S. and Mahunka-Papp, L. 1994. Two new microdispid (Acari, Heterostigmata, Microdispidae) species from Hungary. Annales HistoricoNaturales Musei Nationalis Hungarici, 86: 119-124. 